\title{
The Personification of the Business Corporation in American Law
}

\author{
Gregory A. Mark $\dagger$
}

The personification of the corporation was once of central concern to American jurisprudence. Diverse political and economic views, phrased in the language of legal discourse, were essential to discussions of the corporation's design, form, function, and operation. After the Second World War, however, the place of the corporation in law had ceased to be controversial, and both theoreticians and practitioners concerned themselves instead with organizational theory and economic analysis of corporate behavior. The corporation as a legal institution ceased to be of interest. The historical and jurisprudential debates which had consumed the energies of some of the leading legal scholars were relegated to the introductory pages of corporation law textbooks, if they were discussed at all. As a result, a modern lawyer knows only that a corporation is considered a legal person but finds that terminology devoid of content.

Nineteenth and early twentieth century lawyers, however, knew that when they called a corporation a person the reference meant something. The Dartmouth College decision defined the corporation for the American bar for much of the nineteenth century. ${ }^{1}$ Handed down in the period when corporations were first emerging as a regular vehicle for economic enterprise, the case held that a corporation was an artificial person that owed its existence more to government than to its corporators and, as a creature of positive law, had only the rights and privileges that obtained from the government's grant. ${ }^{2}$

By the late nineteenth century, however, the process for granting corporate charters had radically changed. Corporations had become, if not commonplace, then at least not unusual. While the artificial corporate person enjoyed favor among businessmen who sought the protections it offered, it had also become the object of

$\dagger$ B.A. 1979, Butler University; A.M. 1980, Harvard University; Ph.D. Candidate, Harvard University; J.D. Candidate 1988, The University of Chicago.

1 Dartmouth College v. Woodward, 17 U.S. 518 (1819).

2 Id. at 636. 
fear among those concerned with the power of concentrated wealth. The states chose to abandon their attempts to regulate corporations through their charters and sought instead to regulate harmful activities, regardless of the form of the economic enterprise. At the same time, the corporate bar sought to release the corporation from the strictures of artificiality and to protect corporate property from emerging regulation. They did so by reformulating the corporation as a species of partnership. While the attempt failed, it laid the groundwork for the conception of the corporation as a real person, which saw the corporation as an autonomous, self-directed entity in which rights inhered. That vision successfully transformed corporate jurisprudence. Later, when the legal realists undermined the concept of rights, the terminology remained, bereft of its theoretical underpinning. ${ }^{3}$ As a result, the rhetorical convention that a corporation is a legal person remains, though the convention utterly fails to capture the understanding of the corporation conveyed by any modern theory. ${ }^{4}$

3 The current state of corporate jurisprudence is neatly exemplified by the contrasting attitudes manifested by the Supreme Court in two recent decisions. In First National Bank of Boston v. Bellotti, the Court rejected and characterized as "extreme" the view that "corporations, as creatures of the State, have only those rights granted them by the State." 435 U.S. 765, 778 n.14 (1978). The Court then proceeded to hold that corporations have first amendment free speech rights. In CTS Corp. v. Dynamics Corp. of America, however, the Court upheld state anti-takeover legislation, stating, "[w]e think the Court of Appeals failed to appreciate the significance for Commerce Clause analysis of the fact that state regulation of corporate governance is regulation of entities whose very existence and attributes are a product of state law." 107 S.Ct. 1637, 1649 (1987). The Court then quoted Chief Justice Marshall's Dartmouth College proclamation that the corporation is an "artificial being" and cited a passage of Justice Rehnquists' dissent in Bellotti, which included the very position the majority in that case had characterized as extreme. Amazingly, Justice Powell wrote both opinions.

- In fact, most corporations textbooks pay scant attention to the history and jurisprudence of the corporation. The autonomy of the corporation is not, for most texts, an issue but rather a given. See, for example, Harry G. Henn, Cases and Materials on the Laws of Corporations 1-8 (1974); Detlev F. Vagts, Basic Corporation Law 1-5 (2d ed. 1979) (a sophisticated introduction setting out some of the theoretical and historical tensions but one which sees corporation law history in linear, accretive, and historicist terms); Lewis D. Solomon, Russell B. Stevenson, Jr., and Donald E. Schwartz, Corporations: Law and Policy, Materials and Problems 1-7 (1982). While recognizing disagreements in historical interpretation, Solomon, et. al., say, "We tend to view the business corporation today as an association of individuals, organized to further a common purpose, and possessing a combination of attributes (e.g., continuity of existence, limited liability, separate legal entity, centralized management and transferability of interests) which distinguishes the corporation from other forms of association. Much of the history of corporations is a chronology of the evolution of those attributes." Id. at 1. 


\section{The Problem of the Corporation}

American law has always recognized that people's activities could be formally organized and that the resulting organizations could be dealt with as units. Personification, however, is important because it became far more than a quaint device making it possible for the law to deal with organized business entities. In American legal and economic history, personification has been vital because it (1) implies a single and unitary source of control over the collective property of the corporation's members, (2) defines, encourages and legitimates the corporation as an autonomous, creative, selfdirected economic being, and (3) captures rights, ultimately even constitutional rights, for corporations thereby giving corporate property unprecedented protection from the state. ${ }^{5}$

The concept of the personified corporation resulted from a crisis of legal imagination that accompanied the maturation of America's economy at the end of the nineteenth century and largely preceded the country's entry into what economic historians call the second industrial revolution. It is therefore impossible to understand the jurisprudential debate about the corporation apart from the history of the role played by the business corporation in politics and the economy.

Business corporations, of which there were only a handful when America adopted the constitution, grew in size and number as the country expanded and exploited its resources. ${ }^{6}$ While wealth and reach demanded more and larger institutions in finance and transportation, most citizens retained their revolutionary republican fear of concentrated power and skepticism about the utility of large institutions. ${ }^{7}$ Until nearly the end of the nineteenth century

- It therefore was not until the triumph of personification that corporations could achieve the crucial freedoms to use property in the most fully productive manner, what economic historian David Landes has called "full property." See David Landes, The Unbound Prometheus 16 (1969) ("full in the sense that the various components of ownership were united in the person or persons of the possessor, who could use the object of ownership and dispose of it as he saw fit").

- Oscar and Mary F. Handlin, in Origins of the American Business Corporation, 5 J.Econ.Hist. 1, 22-23 (1945), see the modern corporation as a product of a time no earlier than the Jacksonian period. Rostow sees the take-off in the American economy a few years later, in the late 1840s. See W. W. Rostow, The Stages of Economic Growth 36-37 (1960). He also notes that the take-off is "preceded or accompanied by radical change in . . . market organization." Id. at 51. While corporations had not yet achieved the full property status, they had ceased to be unusual ways of organizing capital by the late $1840 \mathrm{~s}$.

? See Handlin and Handlin, 5 J.Econ.Hist. at 18-19 (cited in note 6); Drew R. McCoy, The Elusive Republic 68-69, 148-52 (1980). Even the principles of economics were anti-corporate. See Adam Smith, 1 The Wealth of Nations 144-46, 470 (R.H. Campbell, A.S. Skinner, and W.B. Todd, eds. 1976). 
business was generally conducted by single proprietorships or partnerships rather than corporations. ${ }^{8}$ Industrial enterprises in particular, because they did not partake of the public character of utilities or transportation facilities, remained the archetypal private and personal business concern.

The radical rethinking of the role of the corporation at the end of the nineteenth century was but one aspect of a newly emerging society. Early in the century, institutional barriers to the dynamic use of property were rapidly replaced by a myriad of state supports for economic development. An entrepreneurial elite whose incomes and fortunes were based on the construction of the country's infrastructure as well as nascent manufacturers replaced an old elite whose wealth had been built on the accumulation of land and agricultural surplus. " This "release of energy," in Willard Hurst's famous phrase, put much of the control of the developing economy, as well as the risks and rewards, into private hands. ${ }^{10}$ While the corporation did not always dominate economic development, nowhere was the transformation of the economy more apparent than in the emergence of a private law of corporations. Corporations had become an individual's tool.

The challenge that private corporations posed to the sovereignty of the state, to its monopoly on the legitimate use of coercive power, was not fully apparent until about the 1880 s because, before that time, the vast majority of corporations were affairs limited in scope and capacity. ${ }^{11}$ Before the $1880 \mathrm{~s}$, the state held larger corporations, such as banks, under comparatively strict reign, through the limited and specified powers granted in their charters of incorporation, through strict construction of those charters by the courts, and through special classes of laws, such as banking laws, designed to regulate the specific affairs of their undertaking. ${ }^{12}$

${ }^{8}$ See Thomas R. Navin and Marian V. Sears, The Rise of a Market for Industrial Securities, 1887-1902, 29 Bus.Hist.Rev. 105 (1955). Navin and Sears emphasize that even some of the largest industrial concerns in the nation were closely held by families. The large corporate enterprise was limited to the railroads; the publicly held corporation was almost nonexistent among industrial enterprises.

- The classic studies are Oscar Handlin and Mary Flug Handlin, Commonwealth (1947) and Louis Hartz, Economic Policy and Democratic Thought (1948). Two recent studies demonstrate that the distributional effects of this growth were uneven, both geographically and by class. See Harry N. Scheiber, Ohio Canal Era (2d ed. 1987) and Morton J. Horwitz, The Transformation of American Law, 1780-1860 (1977).

${ }^{10}$ James Willard Hurst, Law and the Conditions of Freedom in the Nineteenth-Century United States 3-32 (1956).

${ }_{11}$ George Heberton Evans, Business Incorporations in the United States 1800-1943 1419 (1948).

12 James Willard Hurst, The Legitimacy of the Business Corporation in the Law of the 
In that sense, America's large businesses continued to be seen as existing by virtue of the state's wishes.

By the late nineteenth century, however, this state of affairs was no longer tenable. Extremely large businesses were often the property of one man or a closely-knit family. Increasingly, however, large businesses adopted the impersonal management structures that characterized the railroad corporations, heretofore the nation's largest economic units, and were no longer clearly owned by one individual or a family, ${ }^{13}$ Moreover, many of these enterprises were based on manufacturing and trade, and they struck almost no one as existing at the state's behest.

If the marriage of the large business to the corporation inverted the public idea of a corporation from tool to disembodied entity and of business from personal to impersonal, it positively traumatized legal thinking. While tradition, caution, and preference had established corporate property as private, the place of the corporation in law was deeply ambiguous. With characteristics resembling those of individuals as well as governments, the large corporation did not fit well into a legal system designed to mediate conflicts between individuals and between individuals and government. The growing divergence throughout the century between municipal and business corporations suggested that legal thinking would regard the business corporations as more private than public, but it did not suggest how a private law of individuals would become a private law of individuals and corporations. ${ }^{14}$

Several conceptions of the corporation were available to theorists and policy makers. Corporations could have been seen as analogous to either individuals or governments. Alternatively, these analogies could have been rejected and theorists and policymakers could have developed an entirely new body of law to supersede contemporary doctrine. The debate over the alternatives was conducted not only in the theoretical and jurisprudential disputes which raged among scholars and jurists, but also in the counsel offices and court chambers where practicing lawyers struggled with the challenge that this growing anomaly presented.

Late nineteenth century America was prepared to think about

United States 1780-1970 4-18 (1970).

${ }^{13}$ Alfred D. Chandler, Jr., The Visible Hand 79-205, 287-89 (1977).

14 See Gerald E. Frug, The City as a Legal Concept, 93 Harv.L.Rev. 1057, 1095-1120 (1980). For an extended treatment of this evolution using the city of New York as an example, see Hendrik Hartog, Public Property and Private Power: The Corporation of the City of New York in American Law, 1730-1870 (1983). 
a new approach to governing the production and distribution of the country's growing wealth. Visionary industrial intellectuals, utopians and reformists alike, were widely popular in the last quarter of the nineteenth century. They sought ways that a new order might be integrated into, or even supplant, existing society. ${ }^{15}$ Nor was the legal community immune to desires to recast its own place in the polity. The codification movement, an attempt to render the common law into unified statutes embodying democratic principles suitable to a modern society, demonstrated that at least some members of the fraternity were dissatisfied with the way law was practiced and with some of its political foundations. It was an effort, however, that was unable to capture the imagination of the majority of the bar though it remained an important issue in some areas of the country until the $1880 \mathrm{~s}$, precisely the time when the corporation question began to arise. ${ }^{16}$ Its experimental capacity both diverted and enervated by the struggles over codification, legal imagination produced no new and transcendent vision of the corporation.

Even without such a vision, however, American legal thinking underwent a profound reformation. A different corporation was created, one in which industrialism's new found powers ultimately equaled some of those of a government, but whose new conceptual underpinnings were clothed in older language and symbols. It might seem that as businesses grew in the mid-nineteenth century, jurists would have rethought the corporation's position in society based on its increasing ability to concentrate economic power, especially since the large corporations of the time, such as railroads and banks, were acknowledged to have public goals even though they were private institutions. Had jurists focused on economic power, the analogy of a corporation to a government might have forcefully suggested itself.

This analogy was doomed to failure, however, because of the tendency to think of dynamic property as a private matter. Earlier failures of enterprises such as publicly owned canals, some of which had driven states into bankruptcy or near bankruptcy, cast a pall on direct government ownership and management of anything

${ }^{15}$ The literature on late nineteenth century reform is voluminous. The best introduction to the period is Robert H. Wiebe, The Search For Order: 1877-1920 (1967).

${ }^{16}$ Lawrence M. Friedman, A History of American Law 403-11 (2d ed. 1985). Ironically, the one area where the codifiers achieved some real success was in commercial law, where traditional practice was written into statutes. This success inhibited even the incremental ability of the courts to change an operating conception of commercial relations and helped force the legal community to look outside standard legal texts for ideas. 
resembling a business. ${ }^{17}$ Although it restricted the powers of municipal corporations, the willingness of the states to grant public powers and other subsidies to private corporations while simultaneously restricting the powers of municipal corporations suggests that government was happy to forgo both the direct risks and rewards of economic development.

The unwillingness of the legal community to see the corporation as an extension of government reflected its awareness of the political conundrum of imperia in imperio. The distinction between public and private spheres was at the heart of the theoretical challenge of intermediary institutions in the legal and political order. ${ }^{18}$ That a second set of public institutions could operate within the sovereignty of the state and federal governments was simply dismissed as beyond the bounds of acceptable thought. And, as changes in state incorporation policies eliminated any notion that incorporation was a special grant from the state, even the public nature of a corporation's purpose could be called into doubt.

\section{The Legacy of Dartmouth College}

Until the last few years of the nineteenth century jurists took for granted that when they called a corporation a person, they were indulging in a standard convention, a kind of legal shorthand, that meant nothing more than treating a group of corporators, and the property each brought to a corporate entity, as a unit instead of individually. For most of the century, personification depended upon two interrelated but analytically distinguishable propositions: that the corporation was an artificial entity and that the corporation existed only through the grant of incorporation from the sovereign. At first glance these propositions appear to be the same, but in fact the first deals with an individualist conception of the use of property and the second with the state's relationship to its

17 See, for example, Scheiber, Ohio Canal Era 135, 176-77, 297-98, 358-59 (cited in note 9). The decline of public enterprise is the major theme of Hartz's study of Pennsylvania. Hartz, Economic Policy and Democratic Thought (cited in note 9).

${ }^{18}$ The corporation poses a theoretical problem for liberal jurisprudence because it is a collection of individuals and wealth that operates more or less autonomously. The common law and the American constitutional system are both liberal legal systems in that they are prepared to mediate conflicts between the government and its citizens. They are less adept at dealing with intermediary institutions, such as the corporation, which can claim, at least in part, both the loyalty of citizens and independence from government control. This comment will use the concept of "intermediary institutions" to describe those associations, both formally and informally constituted, which stand apart from the state and which claim, in one degree or another, the loyalty and attention of citizens. 
citizens. That the two were almost always used together in legal arguments, however, reinforced the view that the corporation was but a legal fiction. Before the corporation could achieve autonomy from state control, legal thought thus had to recognize both that organized collective holding of property was not unnatural and that the state was not the originator of corporate entities. The confusion which surrounded the two issues complicated the attempts by jurists in the last years of the century to synthesize a new conception of the corporation.

At the heart of the assertion that corporations were artificial were the twin beliefs that private property was an individual right and that an individual would not manage the property of others with the same interest with which he cared for his own. These beliefs found expression in law both in overt statements about corporate property and in judicial interpretations of the restrictions placed upon corporations by their charters. These restrictions involved a paradox: on the one hand, the assumption that no corporation could survive without the privileges granted in its charter-because otherwise the property would be better kept by separate individuals - but on the other hand, the concern that the corporation constituted a privilege powerful enough to require restrictions. Each side of the paradox, however, reinforced the view of corporate property as unnatural.

The clearest statements of this early nineteenth century view of corporate property as artificial appear in the seminal Dartmouth College case. ${ }^{19}$ The issue in the case was whether New Hampshire could alter the charter granted to the trustees of the college by George III in 1789. New Hampshire had passed laws that transferred control of Dartmouth from the trustees to a board of overseers appointed by the governor. The Supreme Court held that New Hampshire's acts were an unconstitutional impairment of the contractual obligation of the state, as George III's successor, to the

1817 U.S. 518 (1819). The arguments of counsel as well as the opinions delivered by Chief Justice Marshall and Associate Justices Washington and Story reflect the tension between the need to assert the sanctity of private property and the legitimate sovereignty of the state. A careful reading of the three opinions, however, suggests that the Justices were not always thinking of the same institutions when they discussed chartered corporations. Marshall's opinion, the most celebrated, deals with corporations in the most general terms and, while it is clear that he saw a distinction between public and private corporations, id. at 629-39, he does not specifically mention business corporations. Washington's opinion, the narrowest of the three, is more concerned with contractual obligation than with the nature of the corporation. Id. at 654-66. Story's opinion is the one which resonates most clearly to modern ears. He accepts and elaborates Marshall's distinction and specifically draws business corporations under the protections Marshall outlined. Id. at 667-77. 
trustees.

The distinction between public and private property which underlies the decision rested on the contention that collective property could exist artificially as private property even though the state had chartered the collective property for a purpose which the sovereign found amenable. Indeed, nearly all of Daniel Webster's argument for the college was devoted to proving exactly that, and he addressed the unnaturalness of chartered property directly:

And does the granting of a charter, which is only done to perpetuate the trust in a more convenient manner, make any difference? . . . The very object sought in obtaining such charter, and in giving property to such a corporation, is to make and keep it private property, and to clothe it with all the security and inviolability of private property. The intent is, that there shall be a legal private ownership.

Webster's colleague Hopkinson succinctly summed up the point: "Indeed, there may be supposed to be an ultimate reference to the public good, in granting all charters of incorporation; but this does not change the property from private to public."20

The justices agreed with Webster and Hopkinson. Chief Justice Marshall made the public-private distinction the centerpiece of his opinion for the Court. Casting charters as contracts between the state and the corporators in their collective capacity, Marshall distinguished between public and private incorporations. A public incorporation required a grant of political power, use only of public property, and public objects of incorporation. That the objects of incorporation were congruent with operations that the state could legitimately undertake did not alone transform the corporation's property into public property, and neither did the use of public property. ${ }^{21}$ A private corporation, however, was limited in the exercise of its powers because it "is an artificial being, invisible, intangible, . . . possess[ing] only those properties which the charter of its creation confers upon it, either expressly, or as incidental to its very existence. These are such as are supposed best calculated to effect the object for which it was created."22 Unlike an individual, whose use of property was coextensive with the public good, a corporation was restricted to its objects in the use of its property. The

20 Id. at $573-74,617$.

21 Id. at 629-35. See also id. at 667-69 (Story). Justice Story makes specific references to business corporations, including insurance, canal, bridge and turnpike companies.

22 Id. at 636. 
power of perpetual succession, the capacity to sue and be sued, in short what Marshall called "individuality," were conveniences forming a legal metaphor for an unusual way of holding property. ${ }^{23}$ Marshall and Story, firm believers in private property, of course meant nothing pejorative when they deemed corporations artificial entities; artificiality was the basis on which private property remained secure. The public, in turn, was protected by the careful consideration of charters and the limitations embedded in them.

Judicial interpretation of charters, granted either directly by the legislature or later under the authority of general incorporation laws, followed both the language and structure of Marshall's opinion throughout the nineteenth century. Even under the pressures generated by a growing economy, the courts generally resisted the temptation to stretch charters very far. They did not have to: new charters were being granted regularly for all types of businesses, especially newly emerging manufacturing concerns. While it was still true that even in the large and wealthy states incorporations only rarely exceeded a few dozen per year, the trend pointed toward wider use of the corporate form by businessmen. ${ }^{24}$

In reiterating general principles of what constituted artificial persons and in deciding if corporations came under statutes mentioning "persons," however, the courts began subtly to narrow the Dartmouth College vision of artificiality. Courts began to assimilate artificial persons to natural ones and to draw larger numbers of commercial associations under the rubric of the protected corporation, all the while maintaining the language of artificiality. For example, in 1841, a New York court made the analogy between persons and corporations virtually an equation when it stated that the very purpose of a corporation was the creation of a unit which could transact business as would a natural person. ${ }^{25}$ Various courts affirmed the legitimacy of corporations created by general incorporation laws $^{28}$ and in the early 1880s a federal Circuit Court ruled

${ }^{23}$ Id. at 636-37. Marshall's more explicit use of personification came in anticipating the objection that the power of perpetual succession was a political one. "Its immortality no more confers on it political power, or a political character, than immortality would confer such power or character on a natural person." Id. at 636 (emphasis added). The use of the words "natural" and "artificial" suggests that in both cases he meant that the special powers, in this case perpetual succession, were defined in terms of the entity's property-holding capacity. The natural way to hold property was as an individual human being; the artificial way was as a corporation.

24 Evans, Business Incorporations at 10 (cited in note 11).

${ }_{28}$ The People v. Assessors of Watertown, 1 Hill 616, 620-21 (N.Y.Sup.Ct. 1841).

${ }^{28}$ See Nesmith v. Sheldon, 48 U.S. 812 (1849); Grangers' Life \& Health Insurance Company v. Kamper, 73 Ala. 325 (1882); Lithgow Man. Co. v. Fitch, 5 Ky.L.Rep. 605 (Sup.Ct. 
that the powers granted to an association, not its nominal designation by law, determined whether it was a corporation. ${ }^{27}$ The practice of the courts had long been to treat corporations as persons when they met all the criteria necessary for a natural person to be included under a given statute, ${ }^{28}$ although some courts denominated them persons under looser circumstances. More specifically, a Georgia court ruled that a corporation engaged in the manufacture and repair of machinery was allowed to obtain a lien authorized to individual machinists under the code then in effect, and a Wisconsin court affirmed the personhood of a corporation named in a statute authorizing persons named to construct dams. ${ }^{29}$

Courts were more commonly asked to define the scope of powers granted under corporate charters than to determine whether corporations were included under statutes mentioning persons. Personification meant very little when a charter specified the powers of a corporation and the general rule was to construe charters strictly. ${ }^{30}$ The large number of cases which required judges to decide whether a corporation had exceeded the powers delineated in its charter, however, belied the premises upon which corporate powers were granted in the first instance. If corporations could constantly test the limits of their authority, they contained a dynamism which had not been supposed to exist at the time of Dartmouth College. This robustness undermined the beliefs about collective property which had then prevailed and from which the Court had drawn the inference of the artificiality of corporate property. The courts thus continued to confirm the legitimacy of private property and the propriety of individuals seeking profit through collective organization, while refusing to recognize a corporate personality separate from the summed interests of the individuals who made up the corporation. The strength of organized

1884); Van Etten v. Eaton, 19 Mich. 186 (1869); Abbott v. Omaha Smelting Co., 4 Neb. 416 (1876).

${ }^{27}$ Fargo v. L., N.A. \& C. Ry. Co., 6 F. 787 (C.C.D.Ind. 1881).

28 See for example, United States v. Amedy, 24 U.S. 391 (1826); Douglass v. P. M. S.S. Co., 4 Cal. 304 (1854); Emerson v. Goodwin, 9 Conn. 422 (1833); Western Union Telegraph Co. v. City of Richmond, 67 Va. 1 (1875); Miller's Ex'or v. Commonwealth, 68 Va. 110 (1876).

${ }^{29}$ Loudon v. Coleman, 59 Ga. 653 (1877); Fisher v. Horicon Iron \& Man. Co., 10 Wis. 351 (1860). But see Betts v. Menard, 1 Ill. 395 (1831) (corporations should be treated as persons only when necessary to give effect to the terms of their charters).

so Where there was ambiguity in its wording, a charter was construed strictly against the corporation. See Perrine v. Chesapeake \& Delaware Canal Co., 50 U.S. 172 (1850); Rice v. Railroad Co., 66 U.S. 358 (1861); Minturn v. Larue, Fed.Cas.No. 9, 646 (1858); Tompkins v. Little Rock \& Ft. S. Ry. Co., 21 F. 370 (1883). Furthermore, powers did not flow by implication. See Moran v. Commissioners of Miami County, 67 U.S. 722 (1862). 
property and the limitations on the corporate form forced the bar to ponder the fate of corporations and to wonder what might replace them. ${ }^{31}$

The public's anti-corporate sentiment stemmed from the very thing that made corporations successful: their ability to concentrate capital. That concentration made real the challenge to the second proposition embodied in Dartmouth College's fictive conception of the corporation, the vision of the corporation as a grant from the state. The grant theory of the corporation was rhetorically the more powerful of the two propositions because it invoked the hierarchy of power which legitimated the modern state. The contraposition of state and individual citizen which characterized the theory of society that prevailed in Western political thought put all intermediary institutions in jeopardy. As such an institution, the corporation had to derive its powers from the state or else it would be perceived as a challenger to its authority. The successive stripping away of first the symbols and then the substance of that vision made clear the challenge the corporation presented.

At the time of Dartmouth College, of course, the questions about the power of intermediary institutions were not so apparent. Webster's oration before the court fully explicated the necessarily derivative place of the corporation. While the contract theory of incorporation developed in Dartmouth College was clearly designed to limit the state's ability to interfere with the operation of the corporation, it was equally clear that, as Webster put it, "a corporate existence and capacity are given to the trustees." Chief Justice Marshall extended Webster's reasoning to conclude that a corporation existed "only in contemplation of law;" Dartmouth College had been "created by the crown," not by the corporators, for "[ $t]$ he corporation is the assignee of their rights." 32

That a corporation derived its powers from the sovereign was inherent in the contractual conception of the grant theory. The government granted nothing unless it agreed to the objects of the proposed corporation. The benefits that the corporation was expected to produce were exchanged for the powers necessary to produce them. As Marshall explained, "The objects for which a corpo-

s1 Compare, for example, Andrew Allison, The Rise and Probable Decline of Private Corporations in America, 7 Reports of the American Bar Association 241 (1884) (speculating on the effects of the hostility to corporations) with The Growth of Corporate Organization, 20 Central L. J. 481 (1885) (noting that corporations appeared to be the vehicles behind economic growth despite the hostility).

32 Dartmouth College, 17 U.S. at 553, 636, 642. 
ration is created are universally such as the government wishes to promote. They are deemed beneficial to the country; and this benefit constitutes the consideration, and, in most cases, the sole consideration of the grant." Marshall elaborated on two facets of the contractual grant, that incorporation was prior to collective action and that the sovereign actually considered the request before approving it. The corporators "apply to the government, state their beneficent object, and offer to advance the money necessary for its accomplishment, provided the government will confer on the instrument which is to execute their designs the capacity to execute them. The proposition is considered and approved."33 Justices Story and Washington expanded on Marshall's theory in their concurring opinions, and Story's is saturated with references to the sovereign as originator of corporations. ${ }^{34}$

An egalitarian spirit, however, pervaded early nineteenth century law, insisting that the state limit the special, often monopolistic privileges extended in corporate charters. Even these limited special privileges proved, however, to be an open invitation to corruption for those who sought them and to political favoritism in the state legislatures granting them. Indeed, the anti-corporate spirit tended to focus more on the privileges and the corruption of favor seekers than on the idea of incorporation itself, though in some minds the two were inseparable. In a remarkable innovation in political economy, the Jacksonians sought to foster legislative purity as well as restore equality when they demanded and ultimately won universal access to the corporate form, with restrictions on the power of the legislature to grant special perquisites. ${ }^{35}$

Free incorporation did more than salve the political conscience of Jacksonian America; it changed the character of the business corporation by undermining a central premise of Dartmouth College. American incorporation practice had once helped to sustain belief in the artificiality of the corporation by suggesting that the

${ }^{33}$ Id. at $637-38$.

${ }^{34}$ For Justice Washington's opinion, see id. at 654-66. Washington devotes four pages to explaining the rights and obligations of each party to a grant. The first eleven pages of Justice Story's opinion examine the nature of corporations as then conceived and explicitly includes business corporations. Id. at 666-77. Clearly, he saw the business corporation and the charitable corporation in the same light insofar as their relationship to the state was concerned. Id. at 670-71. Justice Story's discussion of the contractual conception of the grant is fully compatible with Marshall's, id. at 683-84, and he made it clear that he saw a political hierarchy, even if the sovereign voluntarily contracted away some of its superior powers. See id. at 685-86.

3s See Arthur M. Schlesinger, Jr., The Age of Jackson 336-37 (1945); Evans, Business Incorporations at 11 (cited in note 11). 
privilege of incorporation was a considered grant by the state for a quasi-public purpose, often one defined as much by the desires of the legislature as by the incorporators. Free incorporation, however, suggested that the corporate form was an individual's natural tool, as useful a device for independence and growth as a farmer's plow. Under free incorporation the process of chartering ceased to be a legislative matter and became an administrative and procedural one. While state incorporation statutes maintained structural control over the corporate form, the sovereign no longer considered the proposal of the corporators and then granted a charter. Uncoupling special privilege from the charters also weakened the connection of corporations to broader community service. The belief that the privilege of incorporation should have some clear benefit to the larger community gave way to the view that the larger community was served by strengthening the individuals who formed corporations. The states, once the moving force behind the "private" development of banks, roads, canals, and other institutions vital to economic growth, stood by as individuals formed new corporations. With the exception of the building of the railroads, the states' role in superintending economic development after the 1850s was limited to fostering growth by less direct subsidy.

If it had been the intent of the justices in Dartmouth College to mollify the state legislatures with reassurances that in granting charters they had wisely considered each one, the failure of their effort was quickly manifest. The legislatures immediately began to include clauses reserving to the state the power to amend or repeal the charters that they granted. ${ }^{36}$ This assertion of the power of the legislature over its creations effectively overruled Dartmouth College and reestablished state control. In the everyday practice of state government, however, power and its application were sepa-

${ }^{36}$ See Friedman, A History of American Law at 197-98 (cited in note 16). Compare Hurst, Law and the Conditions of Freedom at 66 (cited in note 10). Hurst argues that these reservations indicate that the state legislatures favored dynamic property over secure property. Given the general anti-corporate sentiment in the years which followed Dartmouth College, this interpretation seems problematic. His example, in which states allowed railroads to override the claims of turnpikes and river transport, does not explain why states also included reservations in the charters of the most dynamic organized properties of all, the newly emerging manufacturing corporations. It would seem that these corporations might have benefited more from clauses which explicitly confirmed their right to override the claims of less dynamic property than from reservations. More probably, reservations were simply a reassertion of complete sovereignty. See 1 Rose's Notes on the United States Reports 985-88 (rev.ed. 1917) (discussing Dartmouth College). Especially interesting is a quotation from Justice Field discussing the reservation clause in terms of sovereignty. See id. at 985-86, quoting Tomlinson v. Jessup, 82 U.S. 454, 458-59 (1872). 
rate matters and the states were often less than energetic in supervising their progeny. In the case of some long-standing businesses the courts simply presumed that they were corporations in order to bring the firms under their protection. ${ }^{37}$ More importantly, free incorporation by itself militated against the ability of state legislatures to take responsibility for each corporation created. The search for some scheme to regulate corporate behavior took on a more general outlook than if state legislatures had vigorously tracked the actions of every corporation. The exercise of the police power through general regulations clearly dominated whatever effort the legislatures made concerning individual corporations. ${ }^{38}$ The growing autonomy of corporations, in part the result of the failure of charter-based regulation, was a key part of the corporation problem facing the states in the late nineteenth century. Not until the 1890s did it become clear that while most aspects of corporate structure and behavior were beyond the boundaries of legitimate interference by the state, egregious business behavior fell within the legitimate province of general regulation.

\section{The Partnership Analysis and Santa Clara}

The transformation of the private law of corporations from 1819 to the 1920 s is best described as a move from a circumstance in which a corporation could do only those things specifically allowed by its charter to one in which a corporation could do anything not specifically prohibited to it. As has already been suggested, the rise of general incorporation laws and the general elimination of the special privileges that accompanied special charters played major roles in making the corporation appear to be a natural way to organize property. The regulatory legislation enacted by the states after the Civil War performed much the same function in that it made corporations seem unexceptional. While state governments remained interested in the form business organizations took, the attention of state legislatures turned increasingly to their behavior. This change in emphasis further legitimated the autonomy of the corporation by removing the state even

37 See United States v. Amedy, 24 U.S. 391 (1826); United States Bank v. Dandridge, 25 U.S. 63 (1827); Hager's Town Turnpike Road Co. v. Creeger, 5 Harris \& Johnson 122 (Md. 1820).

${ }^{38}$ The literature is voluminous and the topic has been central to lawyers and legal historians for years. Among the most sophisticated recent works are Harry Scheiber, The Road to Munn: Eminent Domain and the Concept of Public Purpose in the State Courts, 5 Perspectives in Am.Hist. 327 (1971) and James Willard Hurst, Law and Markets in United States History (1982). 
further from the inner life of a corporation. The state had once been the source of a corporation's purpose and power. By the beginning of the Gilded Age the state supplied only a corporation's robes and, for some businesses, a subsidy.

Crucial limitations on corporate activity nonetheless still existed by virtue of a corporation's status. In an expanding national economy perhaps the most important of these was the foreign corporation doctrine. The issue of whether a corporation could conduct business in a state in which it was not chartered first came before the Supreme Court in 1839 in Bank of Augusta v. Earle ${ }^{39}$ A Georgia bank had issued bills of exchange which an Alabama citizen refused to honor because he claimed that the bank was a foreign corporation that consequently had no right to contract in a sovereign state apart from its own. The bank argued that it had the rights of a citizen under Article IV's privileges and immunities clause $^{40}$ and could therefore enter any state and engage in business. Speaking for the Court, Chief Justice Roger Taney held that while corporations did not enjoy the rights of natural citizens, they had the right to do business in other states if they were not excluded by the positive acts of those states. Many states picked up on Taney's suggestion and enacted legislation which regulated, restricted, and sometimes prohibited foreign corporations from doing business within their boundaries. ${ }^{41}$ Until it was possible to supersede such state regulation with friendlier legislation, or overthrow the states' powers altogether and establish the corporation as an entity beyond their powers, corporate interstate expansion was left in an uncertain position. ${ }^{42}$

s9 38 U.S. 518 (1839).

to U.S.Const. art. IV, § 2.

11 See Hurst, Legitimacy at 64-65 (cited in note 12); Alfred H. Kelly and Winfred A. Harbison, The American Constitution: Its Origins and Development, 326-27 (5th ed. 1976). Kelly and Harbison argue that the ability of states to control corporate behavior began to be limited in 1877, and they see Santa Clara Co. v. South. Pac. Railroad, 118 U.S. 394 (1886), as critical to a further limitation on state interference. Hurst agrees in more general terms, dating these limits from the 1880s. Morton Horwitz, however, disputes Santa Clara's signifcance. See Morton J. Horwitz, Santa Clara Revisited: The Development of Corporate Theory, 88 W.Va.L.Rev. 173, 188-90 (1985). All these historians agree, however, on the central role that the new conception of corporate personality played in eventually undermining restrictions on corporate action.

12 The leading case affirming Bank of Augusta is Paul v. Virginia, 75 U.S. 168, 178-82 (1868) (dictum). Extending the principle in 1872, a North Carolina court ruled that a legislature had the right to impose conditions upon the ability of a foreign corporation to sue in its courts. See The Ex. B'nk of Columbia v. Tiddy and Davidson, 67 N.C. 169 (1872). In 1883 a court held that the legislature could forbid, under threat of criminal penalty, the agents of a foreign insurance company from doing business in the state. See Pierce v. The 
In the 1880s it appeared that the time was ripe for a new approach to the corporation. The collapse of the fictive conception of the corporation was evident. Corporate property was no longer considered artificial, and organized business under the umbrella of incorporation was, if not yet the norm, certainly quite common. No one seriously believed that corporations' economic powers stemmed from their charters, though the rhetoric of the grant theory lingered on despite its substantive hollowness. Advocates of regulation were forced to turn to awkward conceptions of businesses "affected with the public interest" to carve out a way to deal effectively with corporate power. ${ }^{43}$ The corporate bar, on the other hand, searched desperately for some way to free its clients from restrictions on interstate operations and regulatory measures, as well as for some rubric under which the businesses could operate in new fields with greater flexibility and control.

Faced with public hostility towards large business and a crippled legal conception of the corporate form, some members of the corporate bar put forward a modification of the fictive person formula of the corporation during the 1880s. These attorneys hoped to expand the rights of corporations while preserving their structural organization by suggesting that the proper way to think of corporations was that they were similar to partnerships. Victor Morawetz, later a member of New York's Cravath firm, first broached this subject in his 1882 treatise on the law of private business corporations. Because it was clear to him that a corporation's powers did not derive from the state, he suggested that "there is no reason of immediate justice to others, why a number of individuals should not be permitted to form a corporation of their own free will, and without first obtaining permission from the legislature, just as they may form a partnership or enter into ordinary contracts with each other." 44 This radical disaggregation of the corporation, however, was not an attempt to increase the vulnerability of corporators or their businesses, but was rather the last attempt to reconceive the corporation while keeping within the common

People, 106 Ill. 11 (1883).

While the privileges and immunities clause remains inapplicable to corporations, the Court eventually found limitations on state power to interfere with foreign corporations inherent in the commerce clause and the equal protection clause. For a comprehensive modern discussion, see Western \& Southern L. I. Co. v. Bd. of Equalization, 451 U.S. 648 (1981).

43 See, for example, Chief Justice Waite's opinion in Munn v. Illinois, 94 U.S. 113, 12530 (1877).

14 Victor Morawetz, A Treatise on the Law of Private Corporations Other Than Charitable $\S 29$ at 24 (1882). 
law framework of the American legal system.

The core of the new proposals was the elimination of the fictive person conception. As Henry $\mathrm{O}$. Taylor, another member of the New York bar, put it, "the fiction of the 'legal person' has outlived its usefulness, and is no longer adequate for the purposes of an accurate treatment of the legal relations arising through the prosecution of a corporate enterprise. By dismissing this fiction a clearer view may be had of the actual human beings interested, whose rights may then be determined without unnecessary mystification." "4s Both Taylor and Morawetz did not wish to abandon the link that Marshall had established in Dartmouth College between private property rights and the corporation, but both felt that better protection was to be had by making explicit the reason why corporate property was sacrosanct. As Morawetz wrote, "the rights and duties of an incorporated association are in reality the rights and duties of the persons who compose it, and not of an imaginary being." 48

Having grounded the protection of corporate property in the rights of the shareholders, the treatise writers also moved to establish the legitimacy of the corporate structure on non-legal foundations. While the grounding of corporate rights in the rights of corporate shareholders entailed a separation of the legal form from the actual business operations of the corporation, this perspective signaled that the vanguard of the corporate bar had given up the view that corporations were an artificial way to hold property and had accepted the corporate form as natural. Taylor strove to synthesize this new understanding: "In 'a corporation,' according to the usual understanding of the term by business men as well as lawyers, exist elements which are the manifestations of law, and physical elements which are in no sense the manifestations of law."47 Morawetz was even sharper in dismissing the notion that the state stood behind all corporations: "The fact that the popular conception of a copartnership is essentially that of a corporation shows that the idea of a corporation does not necessarily imply a grant of corporate power by statute."48

46 Henry O. Taylor, A Treatise on the Law of Private Corporations Having Capital Stock iv (1884).

48 Morawetz, Law of Private Corporations $\S 1$ at 2.

47 Taylor, Law of Private Corporations $\S 23$ at 14 .

18 Morawetz, Law of Private Corporations $\S 28$ at 24 . See also Taylor, Law of Private Corporations $\S 60$ at 34 (arguing that "under the general enabling statutes, the importance of the 'special sanction' has passed away, and a corporation usually requires no more special sanction than a limited partnership"). John Norton Pomeroy, reviewing Taylor's work, ar- 
It was now clear that individuals, not the state, empowered corporations. What differences, then, remained to distinguish a corporation from a partnership? In Taylor's eyes, there were but two. First, in a partnership all partners were agents; in contrast, all shareholders were not agents of the corporation. Second, a shareholder could generally remove himself from any liability resulting from corporate action by selling his shares; partners retained liability for actions taken on behalf of the partnership even after they had disposed of their partnership shares. ${ }^{49}$ The two conditions were connected by a single vital thread: partners often managed partnerships actively while most shareholders were passive investors in corporations. ${ }^{.0}$

The case made by these writers was that corporations operate with the flexibility of a partnership and the property protection of an individual, while remaining under the control of a relatively limited body of managers. Morawetz was the more expansive of the two, hoping to free corporate action from the limits of corporate charters. He suggested that the only limitation on the acts of corporations should be that of general public policy: "Inasmuch as the prohibition of the common law against any unauthorized exercise of corporate power is based upon grounds of public policy alone, it seems but reasonable that the effect of this prohibition upon the legal validity of corporate acts should be determined by the requirements of public policy."si While Taylor recognized the legitimacy of charter limitations, he construed these limitations nar-

gued as follows:

The common-law conception of the 'legal personality' of the metaphysical entity constituting the corporation, entirely distinct from its individual numbers, arose at a time when corporations were all created by special charters generally granted by the crown; when very few of them were 'stock' corporations; when . . . the legal status of the corporators was wholly swallowed up in the 'legal person' of the corporation, and when corporations were in reality, as a necessary result from this creation and legal position, monopolies. . . . [O]ur American courts, both State and national, have, with few exceptions, gone on and applied the same language, the same conceptions, and the same doctrines to these associations, which were originally applied to corporations as they existed under purely common-law notions and regulations.

Note, The Legal Idea of the Corporation, 19 Amer.L.Rev. 114, 115-16 (1885) (quoting Pomeroy) (emphasis in original).

40 Taylor, Law of Private Corporations $\$ 61$ at 34 (cited in note 45).

${ }^{30}$ Morawetz also saw this distinction as key. "The business of a corporation is managed, on behalf of the association in its corporate capacity, by particular agents, selected by shareholders. On the other hand, every act and every contract of a copartnership is, in legal contemplation, the act or contract of the individual members of the firm." Morawetz, Law of Private Corporations $\S 3$ at 4 (cited in note 44).

${ }^{81} \mathrm{Id} . \S 31$ at 26 . Morawetz uses similar reasoning to evaluate executed ultra vires contracts. Id. 
rowly, preserving broad managerial control over the fate of corporate funds: "By filing articles of association, or accepting a charter, shareholders agree that the corporate enterprise shall be managed as provided for in the charter, or in the enabling statute and articles of association. Their individual right to manage the funds subscribed they surrender into the hands of a majority of themselves, and into the hands of the officers of the corporation, as provided for in the constitution." About how the objects of incorporations were to be determined, however, Taylor was ambiguous. While suggesting on the one hand that corporate funds were a kind of trust fund dedicated to ends defined in the corporate charter, Taylor on the other hand countenanced state intervention insofar as the public interest required the attainment of these ends and creditor interference when corporate action might "endanger the payment of their claims." The objects were thus transformed from the sole legitimate aims of incorporation to restrictions protecting concerned parties from injury. ${ }^{52}$

This reconceptualization was not just an academic exercise, for a number of courts found the new approach of value. Perhaps the most important decisions demonstrating the inroads of the new vision were The Railroad Tax Cases. ${ }^{33}$ The Circuit Court held that private corporations were entitled to equal protection of the laws under the fourteenth amendment: "It would be a most singular result if a constitutional provision intended for the protection of every person against partial and discriminating legislation by the states, should cease to exert such protection the moment the person becomes a member of a corporation."54 Justice Field, riding circuit, looked through the corporation and saw the property of the shareholders: "To deprive the corporation of its property, or to burden it, is, in fact, to deprive the corporators of their property or

s2 Taylor, Law of Corporations $\$ \S 38,32-37$ (cited in note 45).

s3 13 F. 722 (C.C.D.Cal. 1882), appeal dismissed as moot, San Mateo County v. Southern Pac. R.R.Co., 116 U.S. 138 (1885). See also Circuit Judge Gilbert's remarks in United States v. Stanford, 70 F. 346, 358 (9th Cir. 1895), aff'd, 161 U.S. 412 (1896), for a suggestion as to how long this view retained its currency.

o4 The Railroad Tax Cases, $13 \mathrm{~F}$ : at 744. The fourteenth amendment's due process clause protects "persons." The full text of the fourteenth amendment, $\S 1$, reads,

All persons born or naturalized in the United States, and subject to the jurisdiction thereof, are citizens of the United States and of the State wherein they reside. No State shall make or enforce any law which shall abridge the privileges and immunities of citizens of the United States; nor shall any State deprive any person of life, liberty, or property, without due process of law; nor deny to any person within its jurisdiction the equal protection of the laws.

U.S.Const. amend. XIV, § 1 . 
to lessen its value." 55 Circuit Judge Sawyer, in his concurring opinion, used language even more suggestive of the partnership vision of the corporation. The fourteenth amendment, he suggested, "must, at least, through the corporation include the natural persons who compose the corporation, and who are the beneficial owners of all the property, the technical and legal title to which is in the corporation in trust for the corporators." all, however, is that one of the attorneys for defendant Southern Pacific Railroad was John Norton Pomeroy.

Pomeroy, a professor of law at Hastings Law College, was an early and persuasive proponent of the partnership theory of the corporation. His vision of the corporation was adopted wholesale by Judge Sawyer and was a clear influence on Justice Field. Sawyer, in fact, twice adopted Pomeroy's language as his own in his opinion. While enunciating a distinction between the property rights of corporators and those of the corporate entity, Pomeroy argued that this distinction was of no importance in determining the extent to which corporate property deserved protection.

Whatever be the legal nature of a corporation as an artificial, metaphysical being, separate and distinct from the individual members, and whatever distinctions the common law makes, in carrying out the technical legal conception, between property of the corporation and that of the individual members, still, in applying the fundamental guaranties of the constitution, and in thus protecting the rights of property, these metaphysical and technical notions must give way to the reality. The truth cannot be evaded that, for the purpose of protecting rights, the property of all business and trading corporations is the property of the individual corporators. ${ }^{57}$

Field, while resisting the impulse to quote Pomeroy directly, clearly accepted his reasoning: "[T]he courts will look through the ideal entity and name of the corporation to the persons who compose it, and protect them, though the process be in its name."ss

ss The Railroad Tax Cases, $13 \mathrm{~F}$. at 747.

s8 Id. at 757. He elaborates on this view in the pages of his opinion which immediately follow the quoted statement, reiterating that he finds the protection of corporate property not in the person of the corporation but in the persons of the corporators. What is most interesting about Judge Sawyer's argument is that he cites Chief Justice Marshall's reasoning in Bank of the United States v. Deveaux, 9 U.S. 61, 87-88 (1809), where Marshall looked to the residences of the shareholders to determine the jurisdiction of the court.

${ }^{57}$ The Railroad Tax Cases, 13 F. at 758. See also id. at 760.

so Id. at 748. Justice Field and Professor Pomeroy communicated with each other concerning the cases. The confidentiality of the communication and the high regard each had 
It would have been enough for Pomeroy to have influenced one of the preeminent jurists of his day on so important a topic as the protection of corporate property. But at least one piece of evidence suggests that his reasoning was also adopted by Roscoe Conkling, who argued The Railroad Tax Cases before the Supreme Court $^{58}$ and whose presence on the committee which drafted the fourteenth amendment served as a basis for the theory that the amendment was drafted with corporations in mind. ${ }^{60}$ It is useful to see just what Conkling meant when he referred to corporate persons:

It must be remembered, too, that corporations, as known in England, and also in America, so long as they were created by special grant and charter, were ethically and legally more distinct and independent entities, more substantial and vital "abstractions," than the voluntary associations, which now, under general laws free to all, do business under a corporate or co-operate name, or, in the words of Mr. Justice Grier, "only a fictitious name." Yet it is to such specially created and highly endowed and favored corporations, that most of the authorities referred to relate.

The defendant here, in respect of its property, is in law and in fact but the business style of individual owners united and co-operating in a common undertaking, and who, as mere method and convenience, conduct business through corporate agency. ${ }^{61}$

Conkling was attempting, therefore, to protect property, individual

for the other suggests that Pomeroy's influence reached beyond that of normal counsel appearing before the Justice. See especially the letter from Justice Field to Pomeroy dated 28 March 1883, reprinted in Howard Jay Graham, Everyman's Constitution 106-08 (1968).

${ }^{80}$ The Supreme Court dismissed the case as moot. Because Conkling did not argue the motion to dismiss, he is not listed as attorney of record in the official reporter. See San Mateo County v. Sourthern Pac. R.R.Co., 116 U.S. 138. Conkling did, however, argue the case on the merits before the Court. See 29 L.Ed. at 589.

${ }^{B 0}$ Charles A. Beard and Mary R. Beard, The Rise of American Civilization, 111-113 (rev.ed. 1937).

61 Oral Argument of Roscoe Conkling, San Mateo Case; Arguments and Decisions (Hopkins Railroad Collection, Stanford University) reprinted in Graham, Everyman's Constitution at 606 (cited in note 58). What Conkling has abandoned in his oral argument is the grant theory portion of the fictive conception of the corporation. What remains is a conception of the corporation as nothing more than a web of legal relations between individuals. Furthermore, he has given up the belief that collective property is somehow unnatural. What he has not done is to ascribe to collective property rights independent of, and beyond, the web of individual contracts. Thus, while he recognized the functional unity of corporate property, he did not articulate a theory which would have been able to protect its unity rather than the static value of the property at a given instant. 
property held in corporate form, but not corporate autonomy per se. His infamous distortion of the proceedings of the committee which drafted the fourteenth amendment notwithstanding, Conkling was simply searching for a successful formula to preserve private property from state predations.

The partnership theory of the corporation propounded by leading theorists and then embodied in The Railroad Tax Cases strongly suggests that historians have placed undue emphasis on the importance of the Supreme Court's decision in Santa Clara County v. Southern Pacific Railroad. ${ }^{62}$ In this tax case, the Court proclaimed the corporation a person protected by the due process clause of the fourteenth amendment. Yet, far from representing a self-consciously radical innovation in the scope of fourteenth amendment protections as some have claimed, this case merely affirmed that corporate property was protected as property of the corporators.

The evidence suggests that Conkling and Justice Field, the likeliest sources for a new vision of the corporation in Santa Clara, could not have had in mind anything but the partnership analogy that they had espoused in The Railroad Tax Cases. Thus the Santa Clara Court did not mean to fashion new constitutional doctrine with Chief Justice Waite's terse announcement, "The court

62118 U.S. 394 (1886). Kelly and Harbison, modern historians, have argued that Santa Clara played a critical role in limiting the power of states to control corporate behavior. See Kelly and Harbison, American Constitution at 326-27 (cited in note 41). Of more historic importance, however, was the 1927 publication of Charles and Mary Beards' monumental The Rise of American Civilization. The Beards contended that corporate property after the Civil War flourished under the autonomy granted by the addition to the constitution of the fourteenth amendment and its due process clause. The Beards argued that this "cabalistic clause," ostensibly part of an amendment designed to shelter newly freed slaves, had been cunningly designed to bring under its protective aegis all "persons" that had lacked constitutional cover. Santa Clara was thus simply the judicial expression of the intent, however devious and concealed it had once been, of the amendment's chief authors. Beard and Beard, The Rise of American Civilization at 112-113 (cited in note 60).

By focusing subsequent scholarly attention on the fourteenth amendment, the Beards succeeded in casting the personification of the corporation as a constitutional question and in so doing left the world of day-to-day business law behind. While the Beards correctly sensed the importance of personification, they had its story wrong. Constitutional personification was but the ultimate reification of a personified view of the corporation that had deep roots in legal history.

The Beards were also mistaken in their conspiracy theory of the fourteenth amendment. See the following articles by Howard Jay Graham uncoupling the fourteenth amendment from its cabalistic history: The "Conspiracy Theory" of the Fourteenth Amendment, 47 Yale L.J. 371 (1938) (Part I); 48 Yale L.J. 171 (1938) (Part II); Four Letters of Mr. Justice Field, 47 Yale L.J. 1100 (1938); Justice Field and the Fourteenth Amendment, 52 Yale L.J. 851 (1943). These articles are reprinted and updated in Graham, Everyman's Constitution (1968) (cited in note 58). 
does not wish to hear argument on the question whether the provision in the Fourteenth Amendment to the Constitution, which forbids a State to deny to any person within its jurisdiction the equal protection of the laws, applies to these corporations. We are all of opinion that it does."63 In response to the court reporter's question concerning whether he had correctly heard the Chief Justice's announcement, Waite wrote, "I think your mem. in the California Railroad Tax cases expresses with sufficient accuracy what was said before the argument began. I leave it with you to determine whether anything need be said about it in the report inasmuch as we avoided meeting the constitutional question in the decision." 4 Because court reporters, even Supreme Court reporters, are not sources of doctrine, it is impossible to assume that the court meant to do anything more than accept the argument that corporate property was protected as property of the corporators, no matter what uses the Court's announcement was put to in later cases. Inasmuch as the Court also continued to use the term "person" in describing a corporation, it is clear that the Justices had no intention of dismissing the fictive conception of the corporation, even if, for the purpose of protecting property, they were willing to look to the corporators and not the corporation as the real owner of corporate property.

\section{The Organicist Real Person/Real Entity TheORY OF THE CoRPORATION}

If Santa Clara was not the source of the modern personification of the corporation, but at best only a partial acceptance of the partnership analogy, then whence the modern theory? The answer begins with an understanding of the limits of the partnership analogy. The disjunction between seeing the corporation on the one hand as nothing more than the aggregate property of the shareholders and on the other as a functioning business entity proved impossible to maintain. The partnership analogy ignored two key truths of corporate enterprise: first, that part of the value of corporate property was that corporations were ongoing operations premised on the ability to maintain property as a unit; and, second, that corporators were rapidly losing any responsibility for the workings of the firm. The attempt to reconceive corporations on

63 118 U.S. at 396.

84 Letter from Chief Justice Waite to J.C.B. Davis, 26 May 1886, quoted in Graham, Everyman's Constitution at 567 (cited in note 58) (emphasis added). 
individualist grounds had to face the functional reality that individual corporators were responsible neither for much of the growth within a given corporation nor for the adverse consequences of corporate actions.

What then was required of a successful theory of the corporation? It could maintain no longer that the corporation received its powers from the state and that collective property was unnatural, the premises of the artificial entity theory. Neither could it maintain what was untrue, that the corporation was nothing but the sum of the property of the corporators. A successful theory had to recognize the functional economic autonomy of the corporation, derived initially from the corporators and thereafter from the effective operation of the entity by its management. The corporation's ability to operate successfully depended upon its legitimacy in society at large. Legitimacy, in turn, hinged upon the ability of the theory to describe the corporation accurately enough to make it a legal unit fully equivalent to its place as an economic unit. To do that, the theory had to prescribe the corporation's place as at once subordinate to and independent of government.

That the partnership analogy failed to satisfy the needs of the legal system is evident from the continued use by the courts of the terms artificial or fictive person even while adopting the property protecting reasoning of the partnership analogy. The necessity to describe a corporation as an entity continued to assert itself in the language of the courts.

The legal concern over the character of collectivities was by no means limited to the United States. Very sophisticated disputations, both theological and political, about the nature of associations had long been part of the intellectual discourse of continental Europe, and their resolution had shaped law there for the better part of six centuries. In the middle of the nineteenth century, partly as a reaction to the development of the modern state, the topic began to receive the attention of political thinkers who sought to understand the place of intermediary institutions in society. The most prominent of these thinkers was Otto von Gierke, whose work on the history and theory of associations asserted their legitimacy.

The European literature remained largely unread in America because it was untranslated and seemed inassimilable into the common law tradition. Nonetheless, during the 1890s a number of American and English jurists began to draw on such material. Two works provided the foundation for the debates which would crowd the pages of legal publications in the ensuing years: Ernst Freund's 
1897 The Legal Nature of Corporations, and Frederic Maitland's 1900 translation of Gierke's Political Theories of the Middle Age. ${ }^{65}$

It is a sign of just how deep the question of the legitimacy of the corporation ran that scholars were moved to look beyond traditional Anglo-American texts in their search for a scheme which would accommodate the new reality. Beginning in the 1880 s occasional articles were published in scattered journals speculating on the future of the corporation. From the 1890s, however, the insular American bar was treated to an avalanche of writings on the subject that drew on sources which were often from unfamiliar legal cultures or not legally based at all. Furthermore, much of the literature dealt with the question at a highly abstract level, a mode of thinking about problems of law which was distinctly novel for a community which prided itself on being practical and down-toearth. ${ }^{66}$

6s Ernst Freund, The Legal Nature of Corporations (1897); Otto Gierke, Political Theories of the Middle Age (Frederic William Maitland trans. 1900). Freund was an assistant professor of jurisprudence at the University of Chicago at the time, whose publications had dealt both with historical jurisprudence and private-public relations. Before his graduate work at Columbia University, he had been educated at the Universities of Heidelberg and Berlin. Maitland was the preeminent English legal historian of his time. While Gierke's book explicates the organic background of contemporary continental jurisprudence, Maitland was most interested in combatting both a virulent individualism and potential statism. Maitland's interest in Gierke was thus historical and theoretical; he sought for group autonomy both pedigree and noumenon.

${ }^{B B}$ The intellectual crisis that confronted the legal community may be understood by viewing the problem as a change in a system of legal thought which had to be played out at both theoretical and practical levels. Thomas S. Kuhn's remarkable The Structure of Scientific Revolutions (1962) defines the process of paradigm shift for the sciences, but the theory has broader applications. The core of the book - chapter VI, dealing with the discovery of anomalies unexplainable by reigning theory, chapter VII, demonstrating the profound disruption caused to a self-contained system of thought through the introduction of factors outside its accepted boundaries, and chapter VIII, suggesting that the older paradigm persists until a new one can replace it entirely - defines exactly the situation felt by the American bar as it dealt with the problem of the corporation. J.G.A. Pocock has suggested adopting Kuhn's theory to analyze the problem of change in systems of political thought. As he puts it: "Men think by communicating language systems; these systems help constitute both their conceptual worlds and the authority-structures, or social worlds, related to these; the conceptual and social worlds may each be seen as a context to the other, so that the picture gains in concreteness. The individual's thinking may now be viewed as a social event, an act of communication and of response within a paradigm-system, and as a historical event, a moment in a process of transformation of that system and of the interacting worlds which both system and act help to constitute and are constituted by." J.G.A. Pocock, Politics, Language and Time 15 (1973).

Kuhn's work discusses the discrete discoveries and rediscoveries of parts of the replacement paradigm by sometimes scattered individuals, each trying to solve the same problem, though often in different contexts and quite often uninformed about the nature of each other's work. This description is apt. Both legal scholars and practitioners were reaching the same solution at roughly the same time without realizing how valuable each other's work 
The place of the corporation proved to be one of the most confusing jurisprudential problems of the late nineteenth and early twentieth centuries. ${ }^{67}$ Jurists were drawn to it not simply because it posed an extremely challenging intellectual puzzle, though that was clearly part of the attraction. ${ }^{68}$ The tendency of people, both within and without the legal profession, to personify the corporation was what brought the problem to the forefront of juridical controversies. ${ }^{69}$ The tendency was not just a problem of theory; the image of the corporation that dominated legal thought would determine and legitimate the contours of corporate autonomy. ${ }^{70}$

was in the struggle to formulate a new view of the corporation. Neither should it be surprising that, through sheer inadvertence, as in Santa Clara, some of them stumbled on a formulation which was to become the new paradigm. The hints at a new conception of the corporation in Santa Clara did not bear fruit, however, until the older formulation of the place of the corporation was overthrown and lawyers could begin to make full use of the decision in courts manned by those who understood the new paradigm. See, for the more general changes in the legal order, Arnold M. Paul, Conservative Crisis and the Rule of Law (2d ed. 1976).

The importance of second order statements about the law of the corporation, the jurisprudence of the corporation, is that they reproduce at the most abstract level the changes going on at the level of practice. Influence can only be inferred or guessed at, but what is clear is that the jurisprudential disputes gave a framework to the work of practitioners, conveying information, projecting an image, and defining thought. It is therefore important to consider the jurisprudential literature apart from the work of practitioners. It has its own story and the influence of the practitioners upon it is not always clear. From the point of view of the historian, therefore, it is important to limit any suggestions of direct influence to what is cited. All else constitutes only context.

${ }^{67}$ See Alexander Nékám, The Personality Conception of the Legal Entity 48-50 (1938).

- See Frederic William Maitland, 3 The Collected Papers of Frederic William Maitland, 308-09 (H.A.L. Fisher ed. 1911). The essay, "Moral Personality and Legal Personality," was the Sidgwick Lecture, given at Newnham College in 1903.

"s See Harold J. Laski, The Personality of Associations, 29 Harv.L.Rev. 404, 404-05 (1916); George F. Canfield, The Scope and Limits of the Corporate Entity Theory, 17 Colum.L.Rev. 128 (1917); Bryant Smith, Legal Personality, 37 Yale L.J. 283 (1928); Arthur W. Machen, Jr., Corporate Personality (Part 1), 24 Harv.L.Rev. 253 (1911).

${ }^{70}$ It is vital not to discount the role that language plays in this context, for it is easy for historians and other analysts to fall into reductionism and see the image of the corporation as but the reflection of the economic give and take of the late nineteenth century. The problems of law are problems of political language in the largest sense. They are the verbal constructs of the material relations of individuals and collectivities. As a verbal construct, however, the image of a corporation channels the thinking about corporations and in turn controls the material relations themselves. As Pocock summarizes Kuhn, "In what he [Kuhn] calls periods of 'normal science,' paradigms-controlling concepts and theories-so satisfactorily discharge the intellectual functions expected of them that they authoritatively indicate not merely the solutions to problems, but the kinds of problems which are to be conceptualized as requiring solution; and so, dictating the direction, the pattern, the distribution and organization of intellectual endeavor, indicate further the ascription and definition of authority among the individuals and groups composing the 'scientific community." " Pocock, Politics at 13 (cited in note 66). Because those who dealt with the jurisprudence of the corporation supplied the formula, the language, and the new approaches to understanding the place of the corporation in the society, they led the rest of the bar, instead of simply 
What made the issue so puzzling and appealing was the confluence of concrete historical and abstract theoretical statements, a condition which guaranteed that arguments would be endlessly repeated and summarized in ultimately vain attempts to reconcile the meaning of words such as "person," "artificial," "natural," and even "corporation." The attempts to clarify theoretical claims with a veneer of history ${ }^{71}$ were countered with abstractions used to give meaning to history. ${ }^{72}$ The epistemological challenge was enormous, but behind all the confusion lay the single question of whether corporations, broadly conceived, were natural outcomes of human social life or derivative and sterile creations of positive law.

The problem was characterized first as an issue of historical jurisprudence. Maitland's work used history to attempt to prove that the common law was not a closed intellectual system, that it had borrowed ideas, including ones about the corporation, from the continent. He hoped to transform the individualist precepts which guided the common law, giving it a capacity to deal with collectivities. ${ }^{73}$ Virtually all commentators who followed Maitland agreed with his premises, even if they did not adopt his conclusions. ${ }^{74}$ Maitland's purpose was to legitimate intermediary institutions and to require the common law to come to terms with their reality, "[f]or the morality of common sense the group is person, is rightand-duty-bearing unit."

Maitland and Gierke exposed and criticized the fictive personification theory of association which had historically justified the

reacting to the problem with available jurisprudential tools. As Pocock points out, "under pressure from the idealist-materialist dichotomy, we have been giving all our attention to thought as conditioned by social facts outside itself and not enough of our attention to thought as denoting, referring, assuming, alluding, implying, and as performing a variety of functions of which the simplest is that of containing and conveying information." Id. at 37.

$"$ See, for example, E. Merrick Dodd, Jr., Dogma and Practice in the Law of Association, 42 Harv.L.Rev. 977, 980-84 (1929); Martin Wolff, On the Nature of Legal Persons, 54 L.Quart.Rev. 494, 494-95 (1938).

${ }^{72}$ See, for example, Maitland's equation of the state and corporations in order to help explain the basis for associative life. Gierke, Political Theories at ix (cited in note 65).

${ }^{73}$ See id. at xiv, xxviii-xxx; Maitland, 3 Collected Papers at 310, 314-15 (cited in note 68).

74 See, for example, Nékám, Personality Conception at 52, 96-7 (cited in note 67); Frederick Hallis, Corporate Personality xvi, xli (1930). Nékám and Hallis disagreed with Maitland that anything resembling rights inhered in either groups or individuals simply because rights were based upon human beings.

${ }^{75}$ Maitland, 3 Collected Papers at 314-15 (cited in note 68). See also the summary of Maitland and Gierke in Paul Vinogradoff, Juridical Persons, 24 Colum.L.Rev. 594, 602 (1924). The penetration of American legal insularity is nowhere better illustrated than the publication in a leading American law review of this article, written by an English law professor discussing the jurisprudential issues raised by German and English scholars. 
centralizing of power by the Church and then the state. According to Gierke, the first use of fictive personification came in the thirteenth century by Pope Innocent IV. It was an attempt to harmonize and unify society under God by conceiving of the Church as His instrument, from which organized human activity flowed. In this view the Church conceded to individuals the power to organize institutions inferior to the Church. These institutions existed by the grace of the Church and were therefore fictions, devoid of any ultimate authority. As the state began to displace the Church as the central institution of society, it appropriated the theory which put the Church at the apex of the institutional hierarchy. The early modern state deployed the theory as a justification for bringing under its authority guilds and other organizations which competed for the loyalties of its citizenry. Even in America, where the state's power was suspect, its central role was reflected in the theoretically derivative position of intermediary institutions. ${ }^{76}$

While this fictive theory was triumphant, it never became universal. An organicist view of society grew up among some thinkers, largely as a reaction to the strictly hierarchical view of the canonists and legists, but in part an outgrowth of autonomous historical roots. Standing in vivid contrast to the fictive vision, the organicists saw society as a collection of collectivities, each a legitimate outgrowth of individuals united for purposes of their own. Society formed through a union of these collectivities. Each collectivity had a life of its own, its property not merely co-owned but corporately dedicated to its purposes and not divisible, either actually or theoretically, among its members. These collectivities existed as a matter of fact, not at the behest of a superior body. And while there could be hierarchies within each collectivity and among the collectivities, one could not legitimately infer absolute sovereignty from mere residence at the apex of the hierarchy. Both Maitland and Gierke recognized that the organicist view was not ascendant, but both desired to revivify non-sovereign institutions, difficult though they envisioned their struggle to be. ${ }^{77}$ They thus propounded a theory, one with deep roots in continental history, which they felt legitimated and empowered intermediary institutions.

Their findings catalyzed a transatlantic search for a basis for

76 See Gierke, Political Theories at xxi-ii, xxxii, 87-100 (cited in note 65); John Dewey, The Historic Background of Corporate Legal Personality, 35 Yale L.J. 655, 666-67 (1926).

${ }^{77}$ See Gierke, Political Theories at xxv-xxvi, xxviii, xxxviii, xl, 70-71, 87, 95, 98 (cited in note 65). 
the legitimacy of the corporation. For the corporation, the organicist vision proved an emancipation. The theory saw corporations as natural expressions of desires of the corporators. Consequently, corporations obtained their political and thus legal status independently from the state. From independence was inferred autonomy, an autonomy which presupposed a subordinate position to the state to be sure, but an autonomy that demanded the respect and consequent restraint of the state. Furthermore, the organization of the internal operations of the corporation was freed from the necessity of state sanction. The unfolding of this story by the community of legal intellectuals played a vital role in the actual assertion of corporate autonomy by the practicing bar.

The practical value of the theory was immediately apparent to scholars. The least that could be said for the theory was that it better fit the law to the facts of the corporate world. But its practical value went beyond accurate description; the theory had instrumental value in legitimating the autonomy of corporate life. In reviewing the impact of the organicist theory on corporate personality theory, Frederick Hallis concluded that while nearly all the theorists on the continent and elsewhere had rejected what they conceived to be a useless metaphysical approach, organicist theory served as a useful addition to lawyers' tools. "[I]f therefore juristic concepts are not true universals, they are not pure fictions which have not relation to the true account of the real facts. ... [I]t is a sufficient answer to those who say that juristic science is not concerned with the real nature of social facts, but only with what the lawyer makes of them, to point out that the law has a practical and not a utopian aim." personality attempted to subsume too much, from the state to local clubs to business corporations, the "real nature of social facts" was what had forced the rethinking.

To some, at first, the problem with deciding among the available theories of the corporation was a problem only of wording. If the problem lay with the use of the terms "grant," "artificial," "concession," or "fiction," then the remedy was to cease using the terms. But, of course, the corporation was not of flesh and blood,

${ }^{7 a}$ Hallis, Corporate Personality at xxxiii (cited in note 74). See also id. at xxix, xxxiixxxiv. Though Hallis' work was not published until 1930, he drew on changes in legal thought which began in the mid-nineteenth century and proceeded until the time in which he wrote. His book, an extended review of major thinkers on the subject of corporate personality, should be read in part as a critique of those theories and in part as an exercise in the sociology of knowledge. For Hallis, the interactions of the thinkers he reviews were a vital part of their thought. 
and the stubborn problem of the designation "person" compounded rather than ended the confusion, for there were many entities the law recognized. The problem lay in distinguishing among them. Even the clarifying adjective "real" helped but little, for something artificial could be real. ${ }^{78}$

In fact, the problem ran much deeper than wording. While no theory which failed to solve the terminological problem could have been successful, the reality of not only corporate existence but of the enormity of corporate social, political, and economic influence required a theory based on something besides the premises of the fictive theory. ${ }^{80}$ The counsel of non-lawyers, including the pragmatist philosophers, had suddenly become valuable as jurists sought to legitimate corporate autonomy. These outsiders alerted the jurists to the continuing jealousy of the state, its fear of divided loyalties in its citizenry, the concomitant need for other institutions to assume a subordinate place in society, and, paradoxically, the need to preserve intermediary institutions as autonomous. While the balance of individual thinkers focused their efforts on the fate of the business corporation, many saw its fate entwined with the fate of unions, clubs, and other societies. ${ }^{81}$

What united all the efforts to recognize corporations and other associations as "real persons" or "real entities" relatively autonomous from the state was a common sense approach to associative life. In the eyes of those who insisted upon the real person/real entity theory, the functioning existence of a unit necessarily distinguished it from its members. ${ }^{82}$ Maitland set out the position quite

${ }^{78}$ One commentator discerned the difficulty: "If the personality of the corporation is a fiction, it is at any rate not a fiction so transparent that we can at a glance see the truth behind it." W.M. Geldart, Legal Personality, 27 L.Quart.Rev. 90,96 (1911). The terminological confusion is most easily seen in the many different wordings adopted by the scholars Hallis discussed.

${ }^{80}$ Id. at 95-97; Machen, 24 Harv.L.Rev. at 257-58 (cited at note 69); Arthur W. Machen, Jr., Corporate Personality (Part 2), 24 Harv.L.Rev. 347, 360-61 (1911).

st See Hallis, Corporate Personality at xvii, xix, xxiii, xxx, xxxvii-xxxviii, liii (cited in note 74); Dewey, 35 Yale L.J. at 655, 657, 667 (cited in note 76); Maitland, 3 Collected Papers at 310-12, 394-95 (cited in note 68); Laski, 29 Harv.L.Rev. at 405-06, 425-26 (cited in note 69); Dodd, 42 Harv.L.Rev. at 1010 (cited in note 71); Nékám, Personality Conception at 31 n.15 (cited in note 67); Gierke, Political Theories at xli-xlii (cited in note 65).

${ }^{82}$ Compare Maitland, 3 Collected Papers at 314-15 (cited in note 68); Hallis, Corporate Personality at xxxvii (cited in note 74); Smith, 37 Yale L.J. at 288-89 (cited in note 69); and Max Radin, The Endless Problem of Corporate Personality, 32 Colum.L.Rev. 643, 652-53 (1932) with Dodd, 42 Harv.L.Rev. at 979-81, 984-85 (cited in note 71), who argued that while the courts could not properly recognize as real those entities which did not have the sanction of the state, the legal system needed to recognize all entities as real. Dodd believed that it was the combination of private organization and state sanction which defined corporate existence in a legal sense. It is important to remember that Dodd conceded the reality 
clearly very early in his writings: "[I]f $n$ men unite themselves in an organised body, jurisprudence, unless it wishes to pulverise the group, must see $n+1$ persons. And that for the mere lawyer should I think be enough."

Maitland's use of the word "person" was crucial to his formulation, though later and looser constructions sometimes used the term "entity." "Person" carried with it powerful connotations in Anglo-American jurisprudence. The irreducible unit of the common law was the individual person; if the corporation was a real person, not an artificial creation of the state, was it not entitled to the same respect as any flesh-and-blood person? While Maitland intended to mean by person only "right-and-duty-bearing-unit," the word proved the perfect rhetorical weapon, asserting the panoply of individualist protections for the corporation and shifting the role of the state from guardian to invader of rights.

Ernst Freund, while eschewing the term person, deployed the same rhetorical shield by analogy. The corporation, because it was composed of rights-bearing individuals, could assert its claims as would a person. "All parties to the joint relation have an interest in the preservation of the integrity of the common right as against third parties, - an interest as to which perfect harmony is natural, and which is identical with the like interest of the holder of an individual right." 84

The reality of the corporation apart from its members was becoming clearer as the relationship of the shareholders to the operations of the business became increasingly distant. Neither the corporation nor the shareholders could be taken as agents for the other; the actions of the one only rarely put the other at legal risk.

of association independent of the state; his argument presaged the extreme positivism of the 1930s which argued that no rights inhered in anyone or anything until acknowledged by the state.

${ }_{83}$ Maitland, 3 Collected Papers at 316 (cited in note 68).

s4 Freund, Corporations at 22 (cited in note 65). See also Max Radin, A Restatement of Hohfeld, 51 Harv.L.Rev. 1141, 1159-60 (1938) (arguing that a transference of rights could not occur, but that rights could be created in others). Personification performed a second important service for the real person/real entity theorists: it distinguished the corporation from other recognized social units, such as the family. Personification focused attention on the basis for rights and powers, the integrity of the organization. Organized activity and social coherence were inadequate in themselves. See Maitland, 3 Collected Papers at 390 (cited in note 68); Freund, Corporations at 21-22. Preservation of the functional integrity of the group allowed it to pursue its interests as freely as could a person. The unity of interests, including business interests, made the corporation real, legitimating claims it might have both against outsiders who disrupted its operations and insiders who might seek to disaggregate corporate property. See Freund, Corporations at 14, 22-23; Vinogradoff, 24 Colum.L.Rev. at 594 (cited in note 75); Hallis, Corporate Personality at li (cited in note 74). 
The "life" of the corporation could no longer be identified with that of the corporators. A corporation's actions therefore had to be recognized as autonomous, the product of its organization and management. ${ }^{85}$

Baptized by association with heroic historical organizations, their source and existence no longer a question for debate, corporations simultaneously had begun to spur interest in the control of their operations and purpose. ${ }^{86}$ The abandonment of the corporation as a creature of positive law and the subsequent requirement that the inner life of the corporation defined its autonomy embroiled the juristic community in a debate over what factors, precisely, made corporations persons. The debate centered on the issue of corporate will as a function of corporate personality. Whether a corporation could have a will, how it might be located within the corporation, and how it expressed itself were the subsidiary questions.

At one level the debate simply recapitulated the debate over corporate existence. One scholar, for example, conceded the reality of corporate entities, only to deny that the entity had personality: "In the last analysis, it is men and not legal entities whose rights and liabilities the courts must decide. The corporate entity, or personification, which we call a corporation is regarded as having rights and liabilities for the sake of convenience .... Therefore, the proposition 'A corporation is a person' is either a mere metaphor or is a fiction of law.... But although corporate personality is a fiction, the entity which is personified is no fiction." ${ }^{\text {87 }}$ The assertion that personification was a metaphor, however powerful, left it ill-equipped to deal with the analysis which saw rights and powers actually inhering in corporations. In truth, it was a veiled assertion of a partnership analogy because it saw nothing in a corporation beyond the corporators and their convenience. The experience with the corporation which had doomed the partnership analogy also doomed the effort to see personification solely as a metaphor.

Equally ill-fated were the attempts to animate the corporation, which were not generally taken seriously in America. ${ }^{88}$ Nonetheless, commentators recognized the births and deaths of corpora-

${ }^{85}$ Freund, Corporations at 22-23 (cited in note 65); Canfield, 17 Colum.L.Rev. at 128-30 (cited in note 69); Machen, 24 Harv.L.Rev. at 258-62 (cited in note 69).

86 Writings in the literature of personification after Freund and Maitland indicate the triumph. See, for example, Machen, 24 Harv.L.Rev. at 360 (cited in note 80); Laski, 29 Harv.L.Rev. at 413, 417, 425 (cited in note 69); Dewey, 35 Yale L.J. at 669 (cited in note 76).

${ }^{87}$ Machen, 24 Harv.L.Rev. at 266-67 (cited in note 69).

${ }^{88}$ See id. at 256. 
tions, and accepted that they possessed lives and the powers to will, to act, and to create..$^{89}$ Most who dealt with the topic of corporate personality did not find it necessary to use such constructions. Instead, they saw corporate personality in terms of the legal relationships generated by the material operations of the corporation. This somewhat less anthropomorphic analysis looked to a corporation's structure, its finances, and most important, to its management, in order to locate corporate will..$^{90}$

The ascendance of management strengthened the analytic force of the real person/real entity theory and was in turn legitimated by it. Ernst Freund's brilliant exposition of the notion of undivided control over property within a corporation remains the intellectual foundation of the position of management. In Freund's view, undivided control was the necessary outcome of the nature of corporate property holding. Because an individual corporator could neither use corporate property as a personal asset, nor generally be held responsible for corporate debts, the usual linkage of ownership and control did not exist.

Furthermore, a shareholder could participate in any number of relations with a corporation which would appear contradictory unless a clear division existed between the rights of the corporation and the rights of its shareholders. For example, the power to sue a corporation in which one held stock would be senseless if the corporation were a mere convenience for arranging one's own property..$^{91}$

Control differentiated co-ownership and corporate ownership. The shareholder renounced control over his property and freed himself from responsibility for the consequences of how control was exercised. The interest all shareholders had in maintaining the integrity of corporate property meant that the reassertion of control was also strictly limited. One could sell shares, but only under the rarest of circumstances could one dissolve the entity. The inability to destroy the corporate body stood in stark contrast to the image of the corporation suggested by the partnership analogy,

${ }^{89}$ See for example, Vinogradoff, 24 Colum.L.J. at 595 (cited in note 75); Hallis, Corporate Personality at xxxv (cited in note 74); Nékám, Personality Conception at 32-33 (cited in note 67 ). Nékám's view is the most interesting. Having accepted that human beings and corporations are alike in essential respects, he denied that in either case it necessarily followed that they had rights.

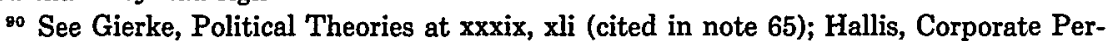
sonality at xxxv (cited in note 74); Henry E. Foley, Incorporation, Multiple Incorporation, and the Conflict of Laws, 42 Harv.L.Rev. 516, 547-49 (1929).

91 Freund, Corporations at 9-10 (cited in note 65). 
making the work of the organicists all the more appealing to corporation theorists in America. The task before those theorists was to explain how management control was legitimate. ${ }^{92}$

For the problem of management control, Freund also had a solution. Modern theories of property began with the assumption that a person's control over and interest in property should be concurrent. In this view the right to control, the preeminent property right, was defined by a person's interest in the property. Freund disputed the universal necessity of such a relationship. The law recognized numerous instances, he said, where interest and control were separate. Property held in trust and joint tenancy were two such instances, though there were also cases in which the interest was inchoate or evanescent and establishing the locus of control was impossible. Other jurists joined with Freund and argued that interest was insufficient to establish control, that control followed from the purpose to which the interest was dedicated. Shareholders in a corporation had voluntarily committed themselves to an enterprise whose purpose required, first and foremost, the unity of their combined property under a single "mind." As Harold Laski put it in 1916, "Just as we have been compelled by the stern exigencies of events to recognize that the corporation is distinct from its members, so, too, we have to recognise that its mind is distinct from their minds."93

Practical experience, not just anthropomorphism, fixed the corporate mind in the management hierarchy. Freund's principle of representation was the basis for all corporate action. Because continuing joint control of corporate property was impossible, corporators delegated their powers to the shareholding majority of their number who in turn named representatives, the management. Human beings within a corporation were its instruments. Just as they acted in pursuit of its purpose, they determined how its purpose was to be interpreted. ${ }^{94}$ Thus, change in managerial personnel did not necessarily effect a change in operations, just as a change in shareholders did not necessarily effect a change in the structure of the entity. Sir Paul Vinogradoff explained the relevance of representation to the powers of management.

${ }^{92}$ See id. at 10, 13; Geldart, 27 L.Quart.Rev, at 97-98 (cited in note 79); Machen, 24 Harv.L.Rev. at 255-56 (cited in note 69).

93 29 Harv.L.Rev. at 415 (cited in note 69). See also Freund, Corporations at 15-22, 3334, 41-43 (cited in note 65); Geldart, 27 L.Quart.Rev. at 99; Vinogradoff, 24 Colum.L.J. at 604 (cited in note 75). Personification asserts itself in Laski's imagery, reinforcing the organic vision of the corporation.

94 Freund, Corporations at 23-25, 28-30, 34; Vinogradoff, 24 Colum.L.Rev. at 595. 
How is the law to deal with such superindividual undertakings? The usual expedient is to assimilate them to live persons. We assign to them a will, i.e., the faculty of taking resolves in the midst of conflicting motives; a governing brain and nerves, in the shape of institutions and agents; a capacity for the promotion and the defence of interests by holding property, performing acts in law, and exercising rights of action in courts. ${ }^{95}$

Corporations, unlike corporeal persons, were immortal. The original purpose to which corporate property was dedicated might cease to be economically relevant, endangering the interests of the shareholders. Because the corporators could not easily dissolve the corporation, indeed because they were an ever-changing community, the power to adapt had to reside with management. Protecting the integrity of the corporate entity required flexibility. In the "brain" of the corporation jurists found the capacity to will change. ${ }^{86}$

Because power to act had been delegated to the majority and its representatives, one looked to them to discover corporate will. Freund put it as follows:

[A]s to corporate will. In its simplest and most obvious meaning this is the personal will of the associates acting under the bond of association. This will is the product of mutual personal influence and of the influence of a common purpose, frequently also the result of compromise and submission. Where under the operation of these factors we obtain a unanimous resolution, we may clearly speak of corporate will. But we are also justified in assuming a correct expression of corporate will, where of the associated persons only a portion, representative in numbers, character, and position, act habitually, while the rest sustain a relation of acquiescence, dependence, or incapacity. ${ }^{97}$

The implications for corporate development were clear enough. A corporation could be bound only by the unwillingness of shareholders to acquiesce in managerial actions, not by limits set in the

${ }^{85}$ Vinogradoff, 24 Colum.L.Rev. at 595.

${ }^{96}$ Freund, Corporations at 34-35, 59-60; Vinogradoff, 24 Colum.L.Rev. at 596-97, 604; Geldart, 27 L.Quart.Rev. at 105-06 (cited in note 79). See also Hallis's discussions of "Pragmatic Jurisprudence" and "The Theory of Subjective Rights as Legally Protected Interests," in Corporate Personality at 75-105, 166-88 (cited in note 74).

${ }^{97}$ Freund, Corporations at 52 (cited in note 65 ). See also id. at 60. 
charter. As Geldart noted: "We may, perhaps, expect that a judge who holds a belief in the personality of a society will be less ready than heretofore to see in trusts and incorporating documents fundamental immutable provisions, more ready to see an implied inherent power of development."98 Freund realized that this will could even be placed in a person who owned no shares in the corporation, completely severing the assumed relationship between interest and control. ${ }^{98}$

By the 1920s the results of the efforts of the real person/real entity theorists were apparent. The psychological assimilation of the corporation to the individual contained the connotative powers of personification while the representative analysis set out by Ernst Freund provided a justification for management's assumption of control of corporate affairs. Freund's conception of the flow of power, from the shareholders to the management, was something of a holdover from the earlier partnership conception of the corporation when it could be said that most members of the corporation were actively involved with its affairs. In the publicly held industrial corporations that were created in the 1890 s and after, however, the shareholders were more properly viewed as creations of managements seeking capital for a variety of purposes. But even Freund anticipated the power of the psychological association when he commented upon the tendency of persons to designate the utterances of corporate officials not as the opinions of the officers themselves, but rather as the point of view of the corporation itself. He had hoped that his approach to corporate organization would avoid the extreme organicism ${ }^{100}$ of continental jurisprudence by shifting attention to the real activities of the corporation while at the same time creating a social compact theory of the corporation. ${ }^{101}$ The undreamt of explosion of the business corporations,

${ }^{88}$ Geldart, 27 L.Quart.Rev. at 106 (cited in note 79). See also Laski, 29 Harv.L.Rev. at 412-13 (cited in note 69), on the inevitable decline of ultra vires. Horwitz, 88 W.Va.L.Rev. at 186-88 (cited in note 41 ) gives the history of its demise.

"Freund, Corporations at 57 (cited in note 65).

100 Organicism at its most extreme subsumed the individual almost entirely. "As biologists spoke of the human body, so political philosophers were wont to speak of the state and society as an organism. The entire philosophy of the Hegelian school was permeated throughout by the analogy, and its politics made no secret of it. To-day, even those who trace their philosophic thought to Hegel find it necessary to moderate the organic theory of society." Hallis, Corporate Personality at 166 (cited in note 74).

${ }^{102}$ Freund, Corporations at 70-71 (cited in note 65). See generally Navin and Sears, 29 Bus.Hist.Rev. 105 (cited in note 8). Navin and Sears make the point most clearly in their discussion of the types of securities issued to attract capital: "A number of the preferred issues carried no voting rights, a fact that is hardly surprising when one remembers that the 'owners' of these companies, in liquidating a part of their investment, usually had no inten- 
both in number and size, had simply consumed Freund's theory and used it in an unexpected manner. The efforts of most jurists during and after the decade were directed toward keeping the psychological association from dominating the representative description. The real person/real entity theorists had wrought better than they knew.

\section{The Decline of Corporation Theory}

After the early 1920s analysts were concerned with how so powerful an image had been created and what its results might be. Critics of the real person/real entity theory had earlier suggested that it was a powerful tool to fill the gaps in legal thought on the corporation. Lawyers and judges resorted to personification if they could come up with no better argument for how a corporation should be treated. ${ }^{102}$ Such insinuations of indolence did not, however, explain why lawyers and judges resorted to such imagery.

The conjunction of the introduction of non-legal materials into the legal process ${ }^{103}$ and the language of personification ${ }^{104}$ had combined to form an image of an autonomous, creative, self-directed economic being. This image permeated the community at large and especially the legal community. The general terms of discourse conditioned the way human beings thought about corporations, their structure, and their actions. As Bryant Smith suggested in an address to the Round Table on Business Associations in 1926, "It is believed that most of the confusion of thought with respect to the subject comes from the disposition to read into legal personality the qualities of natural human personality."

The "reading in" took place despite the vigorous opposition of even the most concerted real person/real entity theorists. Freund had disparaged the use of the idea of any moral personality of the corporation as metaphysical; he was concerned, after all, with the legal relationships its operations generated. Later commentators simply dismissed the imprecise everyday use of the terms "person-

tion of relinquishing control." Id. at 119.

102 See, for example, Machen, 24 Harv.L.Rev. at 351-52, 355-58 (cited in note 80).

${ }^{103}$ Freund anticipated this outcome. See Freund, Corporations at $80-81$ (cited in note 65). For the later analysis see Dewey, 35 Yale L.J. at 657-59 (cited in note 76); Nékám, Personality Conception at 100 (cited in note 67); Elvin R. Latty, The Corporate Entity as a Solvent of Legal Problems, 34 Mich.L.Rev. 597, 606-07 (1936).

${ }^{104}$ See Dewey, 35 Yale L.J. at 662 (cited in note 76); Nékám, Personality Conception at 36, 53-55, 121 (cited in note 67); Latty, 34 Mich.L.Rev. 604-05.

${ }^{105} 37$ Yale L.J. at 291 (cited in note 69) (footnote omitted). See also Wolff, 54 L.Quart.Rev. at 507 (cited in note 71); Nékám, Personality Conception at 35-36, 39, 58-59. 
ality" and "will" as irrelevant. ${ }^{106}$ In doing so, however, they were resorting to an expedient that had early been crushed by the insistence that the everyday experience of the corporation was relevant to its juristic conception. The personified corporation had, by the 1920 s, completely absorbed the imagery which had suited the real person/real entity theorists only as an analogy.

Fear that the imagery would lead to deleterious decisions by the courts motivated the concerned theorists. Their protests were not limited to arguments that the "reading in" was metaphysical and irrelevant. Most considered it simply unnecessary, believing that the representative theory of corporate personality subsumed the everyday usage wherever it might be valuable. ${ }^{107} \mathrm{~A}$ more complex criticism argued that personality per se should not yield substantive decisions. Bryant Smith was quite explicit in his condemnation:

It is not the part of legal personality to dictate conclusions. To insist that because it has been decided that a corporation is a legal person for some purposes it must therefore be a legal person for all purposes, or to insist that because it has been decided that a partnership is not a legal person for some purposes it cannot therefore be so for any purposes, is to make of both corporate personality and partnership impersonality a master rather than a servant, and to decide legal questions on irrelevant considerations without inquiry into their merits. Issues do not properly turn upon a name. ${ }^{108}$

Using corporate personality was, others argued, a blanket either hiding inappropriate reasoning or justifying an improper decision. ${ }^{100}$

The adoption of the real person/real entity theory did not merely raise questions about the use of its imagery by the courts and practicing attorneys. It also led to a profound reassessment of the theory itself, which coincided with the rise of legal realism. The astonishingly rapid erosion of the fictive conception under the pressure of the partnership analogy, followed in turn almost imme-

${ }^{108}$ Freund, Corporations at 75-77 (cited in note 65); Dewey, 35 Yale L.J. at 656 (cited in note 76); Nékám, Personality Conception at 30, 55.

${ }^{107}$ Nékám, Personality Conception at 40, 59-60, 62, 93-96; Dewey, 35 Yale L.J. at 66063; Latty, 34 Mich.L.Rev. at 599-600 (cited in note 103).

${ }^{103}$ Smith, 37 Yale L.J. at 298 (cited in note 69) (footnote omitted).

109 Latty, 34 Mich.L.Rev. at 598, 600, 621-630 (cited in note 103); Nékám, Personality Conception at 37, 42-43, 49, 57-8, 67 (cited in note 67); Wolff, 54 L.Quart.Rev. at 501-03 (cited in note 71). 
diately by the real person/real entity theory, had set in motion an intellectual dynamic which had begun to take on a life of its own. Even while defending the idea that a corporation was real, some legal thinkers, including the realists, had begun to argue that its reality was an unimportant jurisprudential consideration.

What the realists saw as important were the interests that society deemed worthy of protection. It was clear to the realists that society had an interest in the proper functioning of corporate property. The capacity to produce goods and services, to employ the workforce, to innovate, and to grow - these were society's interests and were therefore the objects of the legal system's protections. Individuals also had interests in a functioning system of corporate property that society might wish to protect and promote. Gerard Henderson's landmark work, The Position of Foreign Corporations in American Constitutional Law, made interests, not inherent rights, the premise of his analysis. Concluding his explanation for the protection of corporate property he wrote: "In this sense anything can be made a legal unit, and the subject of rights and duties, a fund, a building, a child unborn, a family. There is no reason, except the practical one, why, as some one has suggested, the law should not accord to the last rose of summer a legal right not to be plucked." 110

The realist jurists and philosophers thus began to argue that theories of corporate personality were entirely fungible. John Dewey's stunning eulogy on the problem closed with a plea for attention to the facts: "[T] he assertion of the simple fact that there is some social reality involved got bound up with the notion of a real, as distinct from fictitious personality. The example, it seems to me, is sufficiently striking to enforce the value of eliminating the idea of personality until the concrete facts and relations involved have been faced and stated on their own account: retaining the word will then do no great harm.".111

${ }^{10}$ Gerard Carl Henderson, The Position of Foreign Corporations in American Constitutional Law 166 (1918) (footnotes omitted).

${ }^{111}$ Dewey, 35 Yale L.J. at 673 (cited in note 76) (emphasis in original). See also Latty, 34 Mich.L.Rev. at 605, 611 (cited in note 103); Radin, 51 Harv.L.Rev. at 1144 (cited in note 84); Nékám, Personality Conception at 44, 46-48, 113 (cited in note 67). Nékám characterized the debate over corporate personality as barren.

Some insight may be had into Dewey's position by reference to his other work. His attack on pure conceptualism may be understood in terms of his general epistemology. In a chapter entitled "Experience and Reason" he wrote, "As the particular was a stepping-stone to image and habit, so the latter may become a stepping-stone to conceptions and principles. But the latter leave experience behind, untouched; they do not react to rectify it." John Dewey, Reconstruction in Philosophy 81 (1920). 
The jurists had adopted a new vision of rights in general and applied it to corporations. This new vision, to one degree or another, denied that rights inhered in anything; it saw only interests to be protected after society determined that the interests deserved protection. The state had become the creator and administrator of rights; the corporation, and for that matter human beings, the subject of rights. In this sense whether corporations resembled human beings was utterly irrelevant because personhood no longer constituted the basis for rights. ${ }^{112}$

The realist attack on conceptualism in legal thought simply displaced corporation theory. Corporations, a leading modern example of human association, were reduced to a bundle of interests recognized by the larger society. The autonomy of the corporation, once rich with political and social as well as economic meaning, had been narrowly confined to the expectations society had of the business unit.

Within a few years the direction of scholarship dealing with the corporation was clear. Adolf A. Berle, a lawyer, and Gardiner C. Means, an economist, published The Modern Corporation and Private Property in 1933. Drawn almost exclusively from materials dealing with corporate finance, it proved to be a remarkably enduring piece of scholarship and its importance as a work of organizational theory is indisputable. The differences between it and earlier scholarship on the corporation are, however, quite startling. It assumed the permanence and the power of the business corporation, its hierarchical structure, and its dominance among the various ways of organizing business operations. Gone was any concern with the political or social justification of corporate autonomy. The book exemplified the inability of realist scholarship to provide a framework for legal thought to reach beyond contemporary conditions. In accepting the contemporary status of corporations, it abandoned the corporation as an example of human association and left it only a model of a business unit, and a static one at that. Berle and Means' suggestion that the acts of large corporations be viewed as a variety of state action, for example, was a failure because it was neither logically nor experientially a necessary result

112 The literature on rights theory is plentiful. For the relationship of the corporation to rights theory at the time, see Latty, 34 Mich.L.Rev. at 601, 615, 630-36 (cited in note 103); Smith, 37 Yale L.J. at 283, 293 (cited in note 69); Foley, 42 Harv.L.Rev. at 518-19 (cited in note 90); Dewey, 35 Yale L.J. at 655 (cited in note 76); Wolff, 54 L.Quart.Rev. at 494, 50509, 511 (cited in note 71); Nékám, Personality Conception at 27-29, 31-38, 43, 69 (cited in note 67). 
of the separation of ownership and control. The suggestion; in fact, seemed to harken back to the grant theory while being blind to the reality of corporate autonomy. In this sense Maitland, for example, was more realistic than Berle and Means because he conceived of powerful intermediary institutions; Berle and Means saw only corporations that were almost as powerful as governments and tried to analogize the corporation to the state.

Whatever the merits of the realist conception as a philosophical or jurisprudential position, the political events which traumatized the 1930s and 1940s, as well as the traditionally strong AngloAmerican belief in rights, combined to provoke a strong reaction to its seemingly amoral view of law. While the realist attack had robbed corporation theory of its larger intellectual content, it had failed to replace the rhetorical tradition of personification because it had nothing to replace it with. The economic and political consequences of personification suggested that the protests of the legal theorists who wanted to dispose of the rhetorical tradition were largely in vain. Even they acknowledged that the autonomy that the real person/real entity theory had fostered had engendered consequences which created issues vital to the future of industrial society. ${ }^{113}$ The most perceptive among them recognized that the very terminology society used to deal with institutions shaped the thought about those institutions. Thurman Arnold, then a law professor at Yale and something of an intellectual eccentric, even among the legal realists, devoted much of his The Folklore of Capitalism precisely to the issue of corporate personification and autonomy. He believed that the imagery of personification had substantially altered the very ways in which people thought about private property, and that this in turn affected business practice and government policy. ${ }^{114}$

Personification with its roots in historic theological disputes and modern business necessity, had proved to be a potent symbol to legitimate the autonomous business corporation and its management. Private property rights had been transferred to associations, associations had themselves become politically legitimate, and the combination had helped foster modern political economy. The corporation, once the derivative tool of the state, had become its rival, and the successes of autonomous corporate management turned

${ }^{113}$ Dewey, 35 Yale L.J. at 664 (cited in note 76); Radin, 51 Harv.L.Rev. at 1144 (cited in note 84); Geldart, 27 L.Quart.Rev. at 104 (cited in note 79).

114 Thurman W. Arnold, The Folklore of Capitalism (1937). See especially chapters VI, VIII, and IX. 
the basis for belief in an individualist conception of property on its head. The protests of modern legists notwithstanding, the business corporation had become the quintessential economic man. 